\title{
Research Paper Economics analysis of Gram in Amravati district
}

\section{口.S. GONDHALI, D.H. ULEMALE AND S.M. SARAP}

See end of the paper for authors' affiliations

Correspondence to :

\section{R.S. GONDHALI}

Shri Shivaji Agriculture College, AMRAVATI (M.S.) INDIA

Email : rahulgondhali25@ gmail.com

\section{Paper History :}

Received : 12.08.2016;

Revised : 08.01.2017

Accepted : 18.01.2017
AbStract : In this study, an attempt has been made to study economic analysis of gram in Amravati district with view to study the Cost and returns, resource use efficiency. The study was based on primary data collected from the Amravati district. Per hectare input utilization for gram indicates that the large farmers were used higher inputs as compared to other farm size group of farmers. Per hectare total cost of cultivation of gram for the sample as whole was Rs. 44349.95 per hectare, gross return from gram at overall level was Rs.71241.85 The input-output relationship at overall size group was 1.60 at Cost ' $C$ '. For the study resource use efficiency of gram, Cobb-Douglas production function was used. In the overall group resources seed, plant protection and human labour were significant.

KEY Words : Gram, Cost and returns, Resource use efficiency

How To Cite This PAPer : Gondhali, R.S., Ulemale, D.H. and Sarap, S.M. (2017). Economics analysis of Gram in Amravati district. Internat. Res. J. Agric. Eco. \& Stat., 8 (1) : 31-36, DOI : 10.15740/HAS/IRJAES/8.1/ 31-36. 